\title{
Cultural-historical resources as initiators of tourism development in Sremski Karlovci
}

\author{
Branislav Sančanin ${ }^{*}$, Goran Perić ${ }^{2}$ Marija Stojiljković \\ ${ }^{1}$ Union - Nikola Tesla University, Faculty of Management, Sremski Karlovci, Serbia \\ 2 Belgrade Business Academy for Applied Studies, Blace Department, Blace, Serbia
}

\begin{abstract}
Cultural heritage is an authentic and unrepeatable resource. Cultural, economic, political, and ecological facts evaluate its observations, both qualitatively and quantitatively. Therefore, we won't exaggerate if we say that cultural heritage should have the status of a strategic resource. In this way, both cultural revitalization and general sustainable development are based on it. The scope and dynamics of conducting complex activities, which unite the restoration, conservation, renovation, revitalization, sanitation, and presentation of protected cultural heritage, condition the preservation and promotion of categorized and immovable cultural heritage. The creation of cultural-historical heritage of Sremski Karlovci and its gradual and systematic tourist valorization are the basis for deepening our understanding of its potential. This potential is based on the effective politics of heritage management. It can become an experience and provide pointers for sustainable development. Establishing a correlation between the most important attractions and multipliers supports the necessary move from the multidisciplinary approach to tourism development to an interdisciplinary one. This approach should help one shape and achieve the goals of the development of culture and tourism by relying on cross-sector and interdepartmental connections, and continued cooperation.
\end{abstract}

Keywords: heritage, culture, tourism, Sremski Karlovci

JEL classification: L83, Z32

\section{Kulturno-istorijski resursi kao generatori turističkog razvoja Sremskih Karlovaca}

Sažetak: Kulturno nasleđe predstavlja autentičan i neponovljiv resurs čije se refleksije kvalitativno i kvantitativno vrednuju kulturnim, ekonomskim, političkim i ekološkim činjenicama. Stoga nije preambiciozno ako kažemo da kulturno nasleđe treba da ima status strateškog resursa, na kojem se zasniva kulturna samorevitalizacija, ali i sveukupni održivi razvoj. Očuvanje i promocija kategorizovanog nepokretnog kulturnog nasleđa uslovljeni su obimom i dinamikom izvođenja složenih zahvata koji integrišu obnovu, konzervaciju, restauraciju, revitalizaciju, sanaciju i adaptaciju zaštićenog kulturnog nasleđa. Mapiranje kulturno-istorijskog nasleđa Sremskih Karlovaca i njegova postupna i sistematična turistička valorizacija predstavljaju bazičnu platformu za razumevanje i produbljivanje svesti o potencijalu koji, na bazi efikasnih politika upravljanja nasleđem, može postati iskustvo i putokaz za održivi razvoj. Uspostavljajući korelaciju između najvažnijih resursnih atrakcija i multiplikatora, protežira se neophodnost iskoraka sa multidisciplinarnog pristupa razvoju turizma na interdisciplinarnu platformu. Takav pristup trebalo bi da obezbedi integrisano

* branislav.sancanin@famns.edu.rs 
definisanje i realizaciju ciljeva razvoja kulture i turizma, kroz međusektorsko i međuresorno povezivanje i kontinuiranu saradnju.

Ključne reči: nasleđe, kultura, turizam, Sremski Karlovci

JEL klasifikacija: L83, Z32

\section{Introduction}

Resource potentials of Sremski Karlovci - a historic city - are perceivable in its cultural, historical, urban, and architectural values. These have constantly been enriched since the end of the 17th century when the first facilities in the city center were found. The political significance and role of Sremski Karlovci can be traced back to 1713 when it became the center of the Metropolitanate. The construction works were the answer of the then needs for public facilities (Provincial Institute for the Protection of Cultural Monuments, 2019). Sremski Karlovci was officially the base of the Metropolitanate of Karlovci and patriarchate until 1920 when all of its eparchies became a part of the Serbian Orthodox Church (Petković, 2006).

The city was first referred to as "kaštel" - a fortress or city known as "Karom" - in 1308 (Dimić, 2014), even though the archeological findings on the site Selište were from the early Neolithic period. To be specific, they belonged to a Starčevo cultural group (from the 6th millennium BC). Now, there are 15 archeological sites in Sremski Karlovci (Gačić, 2016).

Sremski Karlovci was not only the religious and political but also the artistic center. The most important works of Serbian art were created here. For instance, the new building of the Karlovci Gymnasium which Patriarch Anđelić (German) and his brother Stevan built in 1891. Many called it the most representative Serbian facility in Vojvodina, together with the Patriarchate Court (Bakić, 2015). The architect Vladimir Nikolić drew up plans for monumental buildings: Theological Seminary (1900), the People's Funds Palace (1901), Stephaneum (1903), and Elementary School (1913) (Dimić, 2011). The Orthodox Cathedral of St. Nicholas was built in 1762 during the rule of the metropolitan bishop Pavle Nenadović. Previously, that location boasted a temple dedicated to the same saint. The building received

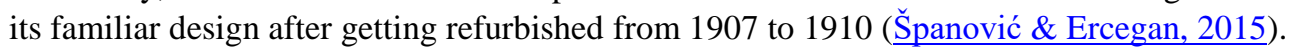

The protection and promotion of the categorized and immovable cultural heritage are determined by the scope and dynamics of performing complex activities. These are conducted on restoration, conservation, revitalization, sanitation, and adaptation of protected cultural heritage. Lučić (2018) notes that cultural heritage is constantly exposed to different influences in the urban context. Thus, its protection in this environment is demanding. This is the reason why research papers are the only ones safeguarding its memory. Yet, it is paramount to view the protection of cultural-historical values and spatial whole as a necessity. However, it is important to note that it is not a sufficient condition for the development of Sremski Karlovci. Those working on urban development should strive to achieve a compromise between unique cultural and historical heritage preservation, and the modern way of living and conducting business. They should attaint this by respecting the authenticity, continuity, and integrity of inherited values. Therefore, we can observe that cultural-historical heritage should not only be brought into a spatial-temporal relationship. Rather, it is vital to establish continuity through time.

There is a general consensus that a historic city is the result of a long and dynamic process of the historical stratification systems. In addition, the authors agree that it should not be perceived as a "museum", rather it is an organism that can adjust to the needs of modern life (Š́ekarić, 2015). 
The Law on the restoration and cultural-historical heritage and stimulation of development in Sremski Karlovci provides a legislative framework. It determines the general conditions for the renewal and presentation of cultural-historical heritage of Sremski Karlovci ${ }^{1}$. The law has created a systematic platform that can renew cultural-historical heritage, which has the status of cultural property. In this way, all activities are under control so that those, which could undermine the authenticity of the urban architecture, artistic and ambient qualities of cultural property or ecological values, could be prevented (Official Gazette of Republic of Serbia, 1991).

The Central Catalogue of immovable cultural properties of Serbia lists the Orthodox Cathedral of St. Nicholas and the Patriarchate Court as cultural monuments of exceptional importance in Sremski Karlovci. The location of the Treaty of Karlowitz from 1699 is listed as a landmark, while the city center falls under the spatial-historical unit. The tomb of Branko Radičević in Stražilovo is a property of great importance. Cultural monuments of great importance are the Chapel of the Nikolić Family on the Čeratsko Cemetary, as well as the tombstones on Magarčev breg and Četarat Cemeteries (Republic Institute for the Protection of Cultural Monuments of Serbia, 2019).

The article should contribute to the creation of a new model of preservation, presentation, and management of the cultural and historical heritage of Sremski Karlovci. This is the basic requirement for the understanding of the relationship between culture and tourism, i. e. the use of culture and the cultural heritage as the resources aimed at satisfying tourists.

\section{Protection and promotion of cultural heritage}

Vujovic (2016) states that the term "cultural heritage" dates back to the second part of the 20th century. The author adds that the term has expanded as a result of the United Nations Educational, Scientific and Cultural Organization and the enactment of the Convention Concerning the Protection of the World Cultural and Natural Heritage. The makers of the Convention agreed to find natural and cultural facilities in every country which would draw everyone's attention. Therefore, they would have a universal significance from the artistic, historical, scientific, or natural aspect (Кирюшина, 2011).

The Operational Guidelines for the implementation of the Convention introduced cultural landscapes in 1996. Furthermore, the Guidelines from 2005 added intangible heritage and cultural differences. As a matter of fact, the UNESCO Conventions are universal platforms for global cooperation and creation of a holistic management model for culture which is based on human rights and values. The UNESCO significance is not only reflected in the protection of cultural heritage, but also in its educational activities and encouragement of sustainable cultural and tourism projects.

The Council of Europe's Framework Convention on the Value of Cultural Heritage for Society (Council of Europe, 2005) defines cultural heritage as "a group of resources inherited from the past which people identify, independently of ownership, as a reflection and expression of their constantly evolving values, beliefs, knowledge and traditions. It includes all aspects of the environment resulting from the interaction between people and places through time.”

Although it mostly relies on previous papers and, in some parts, reinterprets the existing definitions, Šekarić (2014) stresses that The Valletta Principles for the Safeguarding and

\footnotetext{
${ }^{1}$ The Law on the restoration and cultural-historical heritage and stimulation of development in Sremski Karlovci has been in effect ever since January 1 1992. (Official Gazette of the Republic of Serbia, no 37/91, 53/93, 67/93, 48/94, 101/05).
} 
Management of Historic Cities, Towns and Urban Areas ${ }^{2}$ closely defines historic cities. The International Council on Monuments and Sites (ICOMOS) defines historical cities and urban areas as witnesses of the past which created them. They are spatial structures, which express the evolution of the society and its cultural identity (ICOMOS, 2011).

\section{Enhancement of cultural tourism}

There are numerous definitions of cultural tourism; however, it is not possible to pick just one, as this is an umbrella term. It covers historical, artistic, ethnic, religious, sports and other forms of selective tourism. Besides, culture and the whole cultural heritage should be perceived through tangible and intangible dimensions.

The World Travel Organization defines cultural tourism as "the movement of persons for essentially cultural motivations such as study tours, performing arts and cultural tours, travel to festivals and other cultural events, visits to sites and monuments, travel to study nature, folklore or art, and pilgrimages” (WTO, 1995, p. 6).

Richards (1996) explains cultural tourism as "the movement of persons to cultural attractions away from their normal place of residence, with the intention to gather new information and experiences to satisfy their cultural needs" (p. 24). At the 22nd session of the UNWTO General Assembly in Chengdu (China), held from September 11 to 16, a new definition of cultural tourism was offered. It moved the focus from tangible to intangible natural heritage: "Cultural tourism is a type of tourism activity in which the visitor's essential motivation is to learn, discover, experience and consume the tangible and intangible cultural attractions/products in a tourism destination” (WTO, 2019, p. 30).

Intangible cultural heritage has a special place in Sremski Karlovci so as to save old customs. One of the most visited events which has a long tradition is Karlovac Grape Harvest (Grožđebal). The event originates from traditional folk festivities which mark the beginning of the grape harvest instead of its end. The aim of the ceremony, which has been taking place in September or October ever since 1992, is to "nurture cultural and spiritual tradition of Sremski Karlovci, enhance tourism, encourage modern winegrowers and winemakers to continue with the winemaking business which they inherited from their ancestors" (Marković, 2011, p. 122).

Cultural heritage provides a unique identity. It also exerts influence on the creation of memorable urban tales. They form the basis for successful marketing strategies which develop cultural tourism and attract new investments (Jakođinska et al., 2015). Cultural heritage and natural landmarks are the basic means of survival and a prerequisite for tourism development (Cvijanović \& Ružić, 2017).

Cultural tourism development is based on tangible and intangible cultural heritage. Hence, as soon as one creates a tourism product, it is expected they will adopt an integrative approach. Apart from the basic tourism offer, this approach devotes its attention to the appearance of the destination. Additionally, it wants to increase tourists' satisfaction. As a result, tourists will be loyal and return to the destination (Sančanin, 2019, p. 7).

Pančić-Kombol (2006) emphasizes that cultural heritage shapes the product and offers it on the market. The product then becomes the primary and secondary reason for traveling. The creation and development of tourism product in cultural tourism depends on the progress of

\footnotetext{
2 The Valletta Principles for the Safeguarding and Management of Historical Cities, Towns and Urban Areas. The principles were passed on the $17^{\text {th }}$ Assembly of the ICOMOS in Paris (2011).
} 
cultural resource management and application of marketing idea that relies on the user satisfaction.

The significance of cultural heritage is visible as it makes a destination more unique, recognizable, and different. Competitive advantage is usually based on it. Tourism can benefit from heritage in that it can make use of all economic advantages (Vrtiprah, 2006). Cultural heritage is a diverse resource. Therefore, it is vital to preserve its uniqueness and integrity in order to maintain social and cultural values for the betterment of the community and society (Petković, 2019).

An increasing number of tourists finds motivation in the intangible cultural heritage. They emphasize their interest in the different cultural content, crafts, rituals, gastronomy, and the interpretation of the nature and universe. On the other hand, the most developed counties promote the cultural heritage by using it as a means of improving tourism (Filipović, 2018).

The altered characteristics of modern-day tourists require a richer and more diverse offer. It undoubtedly hints at a more intensive training of managers and employees. This is to ensure a high-quality project management and create a unique and recognizable cultural and tourism product.

The initiator role of tourism in economic development, as well as the famous multiplicative effects which it creates, will contribute to the increase in direct and indirect employment in all sectors that are connected to tourism (Čerović et al., 2015).

More dynamic development of cultural tourism in Sremski Karlovci, as a strong initiator of the whole economic development, should be in the framework of Tourism Development Strategy of the Republic of Serbia by the year 2025 (Official Gazette of RS, no. 98/2016). Also, Sremski Karlovci Development Strategy by the year 2020 recognizes tourism as one of the strategic fields and identifies the route of its development. Other strategic and methodological documents stress the potential of Sremski Karlovci to develop and promote a tourism product. It should be in accordance with the tourism carrying capacity, as well as with the historical continuity. Also, it should respect the inherited identity (Official Gazette of Municipality of Sremski Karlovci, no. 4/2016).

The basic reasons for recognizing cultural tourism based on cultural-historical heritage in Sremski Karlovci lie in value, protection, preservation of cultural heritage, and empowerment of tourism with new forms. In addition, we find strong reasons in employment and population retention. Another reason is the fact that it can reduce issues caused by seasons.

By respecting the long-term differentiation in tourism (Kotler et al., 2006), Sremski Karlovci has gained numerous comparative advantages:

Location - refers to the location of cultural-historical heritage, hospitality and tourism facilities, as well as cultural institutions. They are situated in places which tourists visit without using transportation which sheds light on the ecological part.

Physical characteristics - preserved cultural-historical heritage, state-protected natural monuments, and hospitality and catering facilities secure stable revenue for tourism, as well as for other sectors without whose existence it is impossible to satisfy visitors.

Staff - this is one of the most important links in attracting and retaining tourists. For this reason, the recruitment and selection process has been established as a continuous activity. Its goal is to employ those who, with their skills, contribute to the achievement of both operative and strategic goals. Education and trainings should respond to the need to satisfy numerous and diverse tourists' demands. 
Services - they are one of the differential advantages on the increasingly demanding tourism market. The implementation of the program which educates, entertains, informs, and leads tourists through events which represent the bygone period of this city on the slopes of Fruška Gora.

Appearance - Sremski Karlovci has not become the center of culture, enlightenment, and religion in a moment. It has taken several centuries for it to achieve this. Cities which have become twin towns with Sremski Karlovci had a positive experience. For instance, Sergiyev Posad (Russia) and Bardejov (Slovakia) ${ }^{3}$. They can contribute to a more diverse and better tourism offer.

Tourism is an obligation as well for the immovable cultural-historical heritage of Sremski Karlovci. It does not often generate the anticipated and required reinvestment. The data regarding the number and type of visitors shows that the groups of tourists who visit Sremski Karlovci are not favorable as they spend little to nothing. Out of 18,541 tourists who used a guide in 2018, a total of 16,402 were children, while 2,154 were adults.

A visit to Sremski Karlovci and introduction to its natural, cultural-historical landmarks, and beautiful scenery, with the aim of developing a positive relation towards national, cultural, and esthetic values, is a part of the second half of elementary education which is taught out of school (Official Gazette of RS, no. 8/17, 27/18, 10/19).

The biggest number of visitors to Sremski Karlovci was recorded in 2002 - a total of 42,307 tourists traveled here. The city recorded a $10.27 \%$ increase when compared to the previous year (The Ministry of Economy and Regional Development, 2009).

Table 1: The number of visitors who used the services of the Tourist organization of Sremski Karlovci in 2016, 2017 and 2018

\begin{tabular}{|c|c|c|c|}
\hline & Local & Foreigners & Total \\
\hline $\mathbf{2 0 1 6}$ & 17,623 & 911 & 18,534 \\
\hline $\mathbf{2 0 1 7}$ & 17,602 & 954 & 18,556 \\
\hline $\mathbf{2 0 1 8}$ & 19,015 & 1,427 & 20,442 \\
\hline
\end{tabular}

Source: The Tourist organization of Sremski Karlovci

Local guests constitute the largest part of the visitors, while foreigners usually come from former Yugoslavian countries. For adult tourists, the tour of cultural-historical heritage, visit of wineries and monasteries of Fruška Gora, as well as the participation in conferences and seminars are the most important reasons for traveling.

Since 2017, there has been an increase in the number of visitors from China and Israel (TOOSK, 2017). Visa waiver agreement with China creates great chances, especially for cultural tourism based on cultural-historical heritage in Sremski Karlovci. The reason for this is the fact that China was globally one of the five biggest markets in 2018. Also, tourism, as one of the biggest global sectors with a $3.9 \%$ growth, has been surpassing the global economy for the 8th year in a row (WTTC, 2019).

\footnotetext{
${ }^{3}$ The Community Assembly of Sremski Karlovci decided that the city should be twinned with Sergiyev Posad and Bardejov on April 24, 2008.
} 


\section{Conclusion}

Strengthening existing results of cultural-historical heritage renewal and encouraging the development of Sremski Karlovci should include the improvement of the standards of conservation, restoration, revitalization, sanitation, and adaptation. Additionally, it should take into account economic, ecological and social factors. Modern times require an innovative and diverse program of cultural-historical heritage. They also demand the creation of a new value.

Directing cultural politics towards the integrative approach based on cultural heritage management will strengthen the European perspective and connect national politics with cultural within the European Union. This approach is unlike the traditional one which stresses the preservation and protection of cultural heritage.

As the cultural tourism development relies both on tangible and intangible cultural heritage, the diversity of tourism offer in Sremski Karlovci should be completed with the intangible dimension.

We should perceive the future development of Sremski Karlovci through the process which will transform resources into tourist attractions. The atmosphere and characteristics of the city, together with the promotion and preservation of unique events, present a potential. They can position Sremski Karlovci on the global cultural map and secure "invisible export" and significant revenue.

\section{References}

1. Bakić, S. (2015). Sremski Karlovci paradigma istorijskog grada u Srbiji [Sremski Karlovci as a Paradigm of a Historic town in Serbia]. U: Zbornik radova druge međunarodne konferencije "Očuvanje i unapređenje istorijskih gradova” (pp. 11-33). Sremski Karlovci: Pokrajinski zavod za zaštitu spomenika kulture.

2. Council of Europe. (2005). Council of Europe Framework Convention on the Value of Cultural Heritage for Society. Retrieved July 11, 2019 from https://rm.coe.int/1680083746

3. Cvijanović, D., \& Ružić, P. (2017). Ruralni turizam [Rural tourism]. Vrnjačka Banja: Univerzitet u Kragujevcu, Fakultet za hotelijerstvo i turizam u Vrnjačkoj Banji.

4. Čerović, S., Barjaktarović, D., \& Knežević, M. (2015). Podrška razvoju turizma kao faktor konkurentnosti Srbije kao turističke destinacije [Support to tourism development as an actor to Serbian Tourism Destination competitiveness]. U: Zbornik radova I Međunarodne naučne konferencije "Konkurentnost turističke destinacije" (pp. 1-8). Beograd: Univerzitet Singidunum. https://doi.org/10.15308/sitcon-2015-1-8

5. Dimić, Ž. (2011). Sremski Karlovci. Sremski Karlovci: IP Kairos.

6. Dimić, Ž. (2014). Čelnici i časnici Sremskih Karlovaca 1308-2014 [Leaders and Officials of Sremski Karlovci]. KC Karlovačka umetnička radionica i Malo istorijsko društvo - Novi Sad.

7. Filipović, N. (2018). Intangible cultural heritage as a motive for choosing the tourist destination Aranđelovac. Menadžment u hotelijerstvu i turizmu - Hotel and Tourism Management, 6(1), 53-62. https://doi.org/10.5937/menhottur1801053F

8. Gačić, D. (2016). Arheološko nasleđe Sremskih Karlovaca [Archaeological Heritage of Sremski Karlovci]. Muzej grada Novog Sada.

9. International Council on Monuments and Sites (ICOMOS). (2011). The Valletta Principles for the Safeguarding and Management of Historical Cities, Towns and Urban $\begin{array}{llll}\text { Areas. } & \text { Retrieved } & \text { May } & \text { 12, }\end{array}$ 

$\underline{\mathrm{f}}$

10. Jakođinska, K., Purhla, J., Sanetra-Šeliga, J., Tylus, K., Tijus, K., Vandesande, A., ... , \& Verpoest, L. (2015). Kulturno nasleđe vredi Evropi [Cultural Heritage is worth Europe]. Krakov: Međunarodni kulturni centar.

11. Кирюшина, Ю. В. (2011). Нематериальное культурное наследие - актуальное понятие современности [Non-Material Cultural Heritage - Actual Concept o the Present]. Retrieved August 10, 2019 from http://izvestia.asu.ru/2011/21/cult/TheNewsOfASU-2011-2-1-cult-01.pdf

12. Kotler, P., Bowen, J. T., \& Makens, J. T. (2006). Marketing for Hospitality and Tourism. $4^{\text {th }}$ edition. Pearson Education, Inc., Publishing as Prentice Hall.

13. Law the restoration of cultural-historical heritage and stimulation of development in Sremski Karlovci (1991). Official Gazette of Republic of Serbia No. 37/91, 53/93 - other law, 67/93 - other law, 48/94 - other law, 101/05 - other law.

14. Lučić, B. (2018). Kastelum akve Sirmijuma [Castellum Aquae of Sirmium]. Građa za proučavanje spomenika kulture Vojvodine, 31, 7-32.

15. Marković, D. (2011). Još litar jedan... [Another liter...]. Katalog izložbe "Vinogradarstvo i vinarstvo Fruške gore”, Muzej grada Novog Sada.

16. Ministarstvo ekonomije i regionalnog razvoja [The Ministry of Economy and Regional Development]. (2009). Master plan za turističku destinaciju Sremski Karlovci sa Fruškom gorom. [Master plan for Sremski Karlovci tourist destination with Fruška Gora].

17. Pančić-Kombol, T. (2006). Kulturno nasleđe i turizam [Cultural Heritage and Tourism]. Radovi Zavoda za znanstveni rad Varaždin, 16-17, 211-226.

18. Petković, G. (2006). Patrijarh Lukijan Bogdanović [The Patriarch Lukijan Bogdanović]. Karlovačke novine 76.

19. Petković, S. (2019). Menadžment kulturnih resursa u turizmu [Management of cultural resources in tourism]. Beograd: Univerzitet Singidunum.

20. Plan generalne regulacije Sremskih Karlovaca [General regulation plan of Sremski Karlovci]. (2016). Službeni list Opštine Sremski Karlovci, br. 4 [Official Gazette of Municipality of Sremski Karlovci, no. 4].

21. Pravilnik o organizaciji i ostvarivanju nastave u prirodi i ekskurzije u osnovnoj školi [A Rule Book on How to Organize and Perform Classes in Nature and Trips in Elementary School]. (2017). Službeni glasnik RS, br. 8/17, 27/18-dr. zakoni i 10/19 [Official Gazette of RS, no. 8/17, 27/18, 10/19].

22. Provincial Institute for the Protection of Cultural Monuments (2019). Sremski Karlovci. Retrieved July 25, 2019 from http://eng.pzzzsk.rs/sremski-karlovci/sremskikarlovci.html

23. Republic Institute for the Protection of Cultural Monuments of Serbia (2019). Immovable cultural property - IMP. Retrieved July 25, 2019 from http://www.heritage.gov.rs/english/nepokretna_kulturna_dobra.php

24. Richards, G. (1996). Cultural Tourism in Europe. Wallingford: CAB International.

25. Sančanin, B. (2019). Historical Heritage in The Function of Developing Cultural Tourism. The Journal of Middle East and North Africa Sciences, 5(5), 6-12.

26. Strategija razvoja turizma Republike Srbije za period od 2016. do 2025. godine [Tourism Development Strategy of the Republic of Serbia 2016 to 2025] (2016). Sl. glasnik RS, br. 98/2016 [Official Gazette of RS, no. 98/2016].

27. Šekarić, B. (2014). Koncept istorijskog grada u urbanoj konzervaciji. U: Zbornik radova prve međunarodne konferencije "Očuvanje $i$ unapređenje istorijskih gradova" [Preservation of Historical Towns in the $21^{\text {st }}$ century] (pp. 11-34). Sremski Karlovci: Pokrajinski zavod za zaštitu spomenika kulture. 
28. Šekarić, B. (2015). Očuvanje istorijskih gradova u 21. veku. [Preservation of historic cities in the 21st century]. U: Zbornik radova druge međunarodne konferencije "Očuvanje $i$ unapređenje istorijskih gradova" (pp. 61-82). Sremski Karlovci: Pokrajinski zavod za zaštitu spomenika kulture.

29. Španović, M., \& Ercegan, S. (2015). Saborni hram i Riznica muzeja Srpske pravoslavne crkve u Sremskim Karlovcima [Cathedral and Treasury of the Museum of the Serbian Orthodox Church in Sremski Karlovci]. Srpska pravoslavna Eparhija sremska.

30. Turistička organizacija Opštine Sremski Karlovci (TOOSK). (2017). Izveštaj o radu Turističke organizacije Opštine Sremski Karlovci br. 156/31-12 [Report on the Work of the Tourist Organization of the Municipality of Sremski Karlovci No. 156/31-12].

31. Vrtiprah, V. (2006). Kulturni resursi kao činitelj turističke ponude u 21. stoljeću [Cultural resources as a tourist supply factor in the $21^{\text {st }}$ century]. Ekonomska misao $i$ praksa, 2, 279-296.

32. Vujović, S. (2016). Kako očuvati i koristiti kulturno nasleđe: doprinos vekova Bača [How to Preserve and Use Cultural Heritage: The Contribution of the Centuries of Bac]. Petrovaradin: Pokrajinski zavod za zaštitu spomenika kulture.

33. World Travel Organisation (WTO). (1995). The State's Role in Protecting and Promoting Culture as a Factor of Tourism Development and the Proper Use and Exploitation of the National Cultural Heritage of Sites and Monument for Tourism.

34. World Travel Organization (WTO). (2019). UNWTO Tourism Definitions. Retrieved August 13, 2019 from https://publications.unwto.org/publication/UNWTO-Tourismdefinitions

35. World Travel \& Tourism Council (WTTC). (2019). Economic Impact 2019 World. Retrieved August 11, 2019 from https://www.wttc.org/-/media/files/reports/economicimpact-research/regions-2019/world2019.pdf 